\title{
Efficacy of commercial synthetic pyrethroids and organophosphates associations used to control Rhipicephalus (Boophilus) microplus in Southern Brazil
}

Eficácia de associações comerciais entre piretroides sintéticos e organofosforados utilizados no controle de Rhipicephalus (Boophilus) microplus na Região Sul do Brasil

Caroline Zamperete Reginato ${ }^{1}$; Gustavo Cauduro Cadore ${ }^{1}$; Fernanda Rezer de Menezes ${ }^{2}$; Luis Antonio Sangioni ${ }^{1}$; Fernanda Silveira Flores Vogel ${ }^{1 *}$

\footnotetext{
${ }^{1}$ Departamento de Medicina Veterinária Preventiva - DMVP, Centro de Ciências Rurais - CCR, Universidade Federal de Santa Maria - UFSM, Santa Maria, RS, Brasil

${ }^{2}$ Programa de Pós-Graduaçấo em Economia e Desenvolvimento - PNPD/CAPES, Universidade Federal de Santa Maria - UFSM, Santa Maria, RS, Brasil
}

Received May 3, 2017

Accepted August 28, 2017

\begin{abstract}
This study evaluated the acaricidal efficiency of synthetic pyrethroids (SP) associated with organophosphates (OP) against Rhipicephalus (Boophilus) microplus populations in the state of Rio Grande do Sul, Southern Brazil. Ticks were collected in 54 cattle farms and tested using in vitro adult immersion test against four commercially available acaricide mixtures of SP and OP. Only one of four acaricides, comprising a mixture of cypermethrin, chlorpyrifos, and fenthion, had a mean efficiency higher than $95 \%$, and was effective in $94.44 \%$ (51/54) of the cattle farms tested. The acaricide with a mixture of cypermethrin, chlorpyrifos, and citronelall had the lowest mean efficiency $(62.11 \%)$, and was effective in 29.62\% (16/54) of cattle farms tested. Furthermore, $R$. (B.) microplus in Southern Brazil exhibited differing degrees of resistance to SP and OP mixtures. The results suggest that the presence of fenthion contributes to the higher efficiency of the formulation with this active principle. This is possibly due to its recent commercial availability, as tick populations have been lower challenged with this product. Monitoring the resistance of ticks to carrapaticides is essential to maximize the efficiency of these products in the control of $R$. (B.) microplus.
\end{abstract}

Keywords: Tick, cattle, chemical control, resistance, Boophilus.

\section{Resumo}

Este estudo avaliou a eficiência acaricida de piretroides sintéticos (SP) associados a organofosforados (OP) sobre populaçôes de Rhipicephalus (Boophilus) microplus no estado do Rio Grande do Sul, Brasil. Carrapatos foram coletados em 54 fazendas de bovinos, testados in vitro pelo teste de imersão de teleóginas, contra quatro associaçóes acaricidas comercialmente disponíveis de SP e OP. Apenas um dos quatro acaricidas, constituído por associação de cipermetrina, clorpirifós e fenthion, teve eficiência média superior a 95\%, sendo eficaz em 94,44\% (51/54) das fazendas testadas. O acaricida com associação de cipermetrina, clorpirifós e citronelal teve menor eficiência média (62,11\%), sendo efetivo em 29,62\% (16/54) das fazendas testadas. Além disso, o $R$. (B.) microplus no sul do Brasil, apresentou diferentes graus de resistência às associações de SP e OP. Os resultados sugerem que a presença do fenthion contribui para a maior eficiência da formulação com esse princípio ativo. Possivelmente, isso ocorre em função da sua recente introdução no mercado, já que as populaçóes de carrapatos foram pouco desafiadas com este produto. Monitorar a resistência dos carrapatos aos carrapaticidas é fundamental para maximizar a eficiência desses produtos no controle de $R$. (B.) microplus.

Palavras-chave: Carrapatos, bovinos, carrapaticida, resistência, Boophilus.

\footnotetext{
${ }^{*}$ Corresponding author: Fernanda Silveira Flores Vogel. Laboratório de Doenças Parasitárias, Departamento de Medicina Veterinária Preventiva - DMVP, Universidade Federal de Santa Maria - UFSM, Av. Roraima, n. 1000, Prédio 44, Sala 5149, CEP 97105-900, Santa Maria, RS, Brasil. e-mail: fefevogel@gmail.com
} 


\section{Introduction}

Rhipicephalus (Boophilus) microplus represents a serious economic threat to the cattle industry in tropical and subtropical areas, particularly in South America. The negative economic impact of tick infestation is caused by a combination of direct and indirect effects on infected bovines, including blood loss, reduced weight gain and milk production, increased risk of myiasis, and transmission of tick-borne diseases (ROCHA et al., 2011; RECK et al., 2014). Losses caused by tick infestation can be minimized by treating cattle with acaricides, but resistance is widespread in countries where $R$. (B.) microplus is well established (FERNÁNDEZ-SALAS et al., 2012; KLAFKE et al., 2017). The use of chemical control against ticks is characterized by a continuous increase of resistance, proportional to the frequency of the application of acaricides (VARGAS et al., 2003; CAMPOS \& OLIVEIRA, 2005). To be licensed in Brazil, a chemical product to be used in the control of tick populations must be at least $95 \%$ effective in a sensitive strain of R. (B.) microplus (BRASIL, 1997). Control of cattle ticks primarily depends on treatment with synthetic acaricides (MILLER et al., 2007); however, the intensive use of chemical formulations leads to a loss of effectiveness of these molecules with the consequent spread of resistance against them, making essential the strategic administration of these products (FAO, 2004).

Indiscriminate use of incorrect concentrations of acaricides has likely contributed to the development of resistance in tick populations, which is aggravated by the increasing numbers of products that combine two or more active ingredients (FAO, 2004). The inefficacy of chemical products in tick control is a major challenge for the cattle industry, and resistance to the main classes of acaricides has been reported in several regions (FERNÁNDEZ-SALAS et al., 2012; RECK et al., 2014; GHOSH et al., 2015). The combination of two different pharmacological bases in a single acaricide is a common practice found at commercial level. The gradual loss of efficacy to acaricides is commonly reported by farmers in the Brazilian state of Rio Grande do Sul, that report the failure of tick control in their herds. Thus, this study aimed to evaluate the acaricide efficiency of synthetic pyrethroids (SP) associated with organophosphates (OP) used to control of $R$. (B.) microplus populations in Rio Grande do Sul, Southern Brazil.

\section{Materials and Methods}

Engorged female $R$. (B.) microplus were collected from dairy and beef cattle in different regions of Rio Grande do Sul from November 2015 to August 2016. Ticks were collected directly from animals in 54 cattle farms located in 28 cities of Rio Grande do Sul in southern Brazil: Alegrete (two farms), Caçapava do Sul (eight farms), Cacequi (two farms), Cachoeira do Sul (two farms), Dilermando de Aguiar (two farms), Encruzilhada do Sul, Faxinal do Soturno (two farms), Jaguari, Jari, Júlio de Castilhos, Lavras do Sul, Nova Esperança do Sul, Nova Palma (two farms), Paraíso do Sul, Pinhal Grande, Restinga Seca, Rosário do Sul, Santa Barbara do Sul, Santa Maria (two farms), Santiago (three farms), São Francisco de Assis (two farms), São Gabriel (five farms), São João do Polêsine, São Martinho da Serra, São Pedro do Sul, São Sepé (five farms), São Vicente do Sul (two farms), and Vila Nova do Sul (Figure 1). In vitro adult immersion tests (AIT) were used to detect susceptibility or resistance to different acaricide mixtures. Farms were selected based

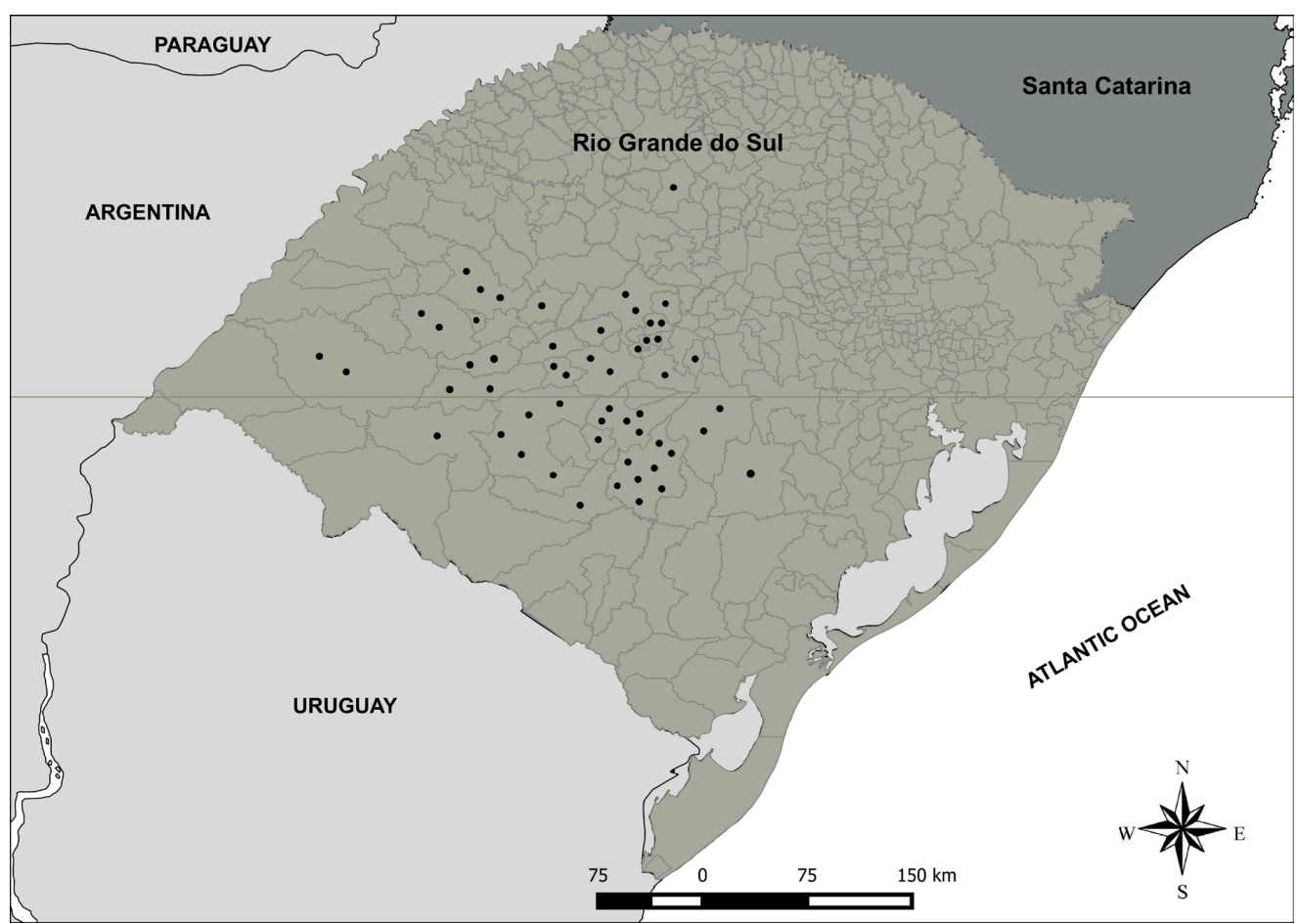

Figure 1. Locations of 54 cattle farms in 28 cities of Rio Grande do Sul, southern Brazil, at which four commercially formulations of synthetic pyrethroids and organophosphates were tested against Rhipicephalus (B.) microplus using in vitro Adult Immersion Test. Spheres indicate the locations of the farms. 
on a historical failure of tick chemical control measures, and ticks were only taken from animals that had not received acaricides in the 30 days preceding collection.

Four commercial acaricide mixtures of SP and OP were tested by AIT, according to the methods set out by Drummond et al. (1973). The chemical compounds belonging to the OP chemical group used in this study were chlorpyrifos, ethion, and fenthion. The chemical compounds belonging to the SP chemical group used in this study were cypermethrin, cypermethrin high-cis, and alpha-cypermethrin. At each farm, approximately 200 engorged females were taken directly from infested cattle. Ectoparasiticide $A$ (Colosso ${ }^{\circledR}$, OuroFino Animal Health) comprised 15\% cypermethrin, 25\% chlorpyrifos, and $1 \%$ citronellal diluted with distilled water to final concentrations of $0.15 \mathrm{mg} \mathrm{mL}^{-1}, 0.25 \mathrm{mg} \mathrm{mL}^{-1}$, and $0.01 \mathrm{mg} \mathrm{mL}^{-1}$, respectively; ectoparasiticide B (Colosso FC30 ${ }^{\circledR}$, OuroFino Animal Health) comprised $15 \%$ cypermethrin, $30 \%$ chlorpyrifos, and $15 \%$ fenthion diluted with distilled water to final concentrations of $0.188 \mathrm{mg} \mathrm{mL}^{-1}$, $0.375 \mathrm{mg} \mathrm{mL}^{-1}$, and $0.188 \mathrm{mg} \mathrm{mL}^{-1}$, respectively; ectoparasiticide $C$ (Flytion ${ }^{\circledR}$, Clarion Biosciences Ltda.) comprised 50\% chlorpyriphos and 6\% cypermethrin high-cis diluted with distilled water to final concentrations of $0.833 \mathrm{mg} \mathrm{mL}^{-1}$ and $0.1 \mathrm{mg} \mathrm{mL}^{-1}$, respectively; and ectoparasiticide D (Potenty ${ }^{\circledR}$, MSD Animal Health) comprised 16\% ethion, $8.5 \%$ chlorpyriphos, and 5\% alpha-cypermethrin, diluted with distilled water to final concentrations of $0.4 \mathrm{mg} \mathrm{mL}^{-1}$, $0.212 \mathrm{mg} \mathrm{mL}^{-1}$, and $0.125 \mathrm{mg} \mathrm{mL}^{-1}$, respectively. All products were commercially available, were used according to recommendations and at concentrations specified by the manufacturers for immersion baths. Distilled water was used for the control group. Each test was performed in triplicate with 10 engorged females per group immersed for $5 \mathrm{~min}$ in $30 \mathrm{~mL}$ of test solution.

Data were analyzed using SAS software (SAS, 1985). Mean efficiency of each acaricide solution was determined using Fisher's exact test with the significance threshold set at 0.05 .

\section{Results and Discussion}

Of the four commercial acaricides tested, ectoparasiticide $A$ had the lowest mean efficiency and ectoparasiticide $B$ had the highest (Table 1). Three of the products analyzed had a mean efficiency lower than 95\% (ectoparasiticides A, C, and D; Table 1). Reports of cattle tick resistance to SP and OP have been recorded for decades (NOLAN et al., 1977). An alternative measure to increase acaricide treatments efficacy against tick populations is the combination of two different chemicals. Combinations of different chemical bases are generally more effective than single molecule formulations (VARGAS et al., 2003). However, these combinations do not always lead to efficiency levels of at least 95\% (CAMPOS \& OLIVEIRA, 2005; MENDES et al., 2007). For instance, in the present study, a mixture of cypermethrin, chlorpyrifos, and citronellal (ectoparasiticide $A$ ) and a mixture of ethion, chlorpyriphos, and alpha-cypermethrin (ectoparasiticide D) did not achieve satisfactory efficiency levels (Table 1).

Each of the analyzed ectoparasiticides exhibited both efficiency $(\geq 95 \%)$ and acaricide resistance $(<95 \%)$ in samples from at least one farm cattle (Figure 2). Ectoparasiticides B and C had satisfactory acaricidal efficiencies $(\geq 95 \%)$ in $51(94.44 \%)$ and
Table 1. In vitro efficiency, using Adult Immersion Test, of acaricide mixtures of synthetic pyrethroids and organophosphates used to control the Rhipicephalus (B.) microplus populations from state of Rio Grande do Sul in southern Brazil.

\begin{tabular}{lcccc}
\hline & A & B & C & D \\
\hline Percentage of farms & $29.62^{\mathrm{c}}$ & $94.44^{\mathrm{a}}$ & $81.48^{\mathrm{b}}$ & $40.74^{\mathrm{c}}$ \\
with efficacy $\geq 95 \%(\%)$ & $(16 / 54)$ & $(51 / 54)$ & $(44 / 54)$ & $(22 / 54)$ \\
Mean efficacy (\%) & 62.11 & 98.76 & 92.14 & 72.06 \\
Amplitude (\%) & $1.2-100$ & $67-100$ & $10.2-100$ & $4.6-100$ \\
Standard Error & +9.31 & +1.46 & +5.4 & +8.42 \\
Lower 95\% CI & 52.8 & 97.3 & 86.74 & 63.64 \\
Upper 95\% CI & 71.42 & 100 & 97.54 & 80.48 \\
\hline
\end{tabular}

Distinct small letters indicate statistical differences by Fischer's exact test $(p<0.05)$. ectoparasiticide $A$ (cypermethrin $0.15 \mathrm{mg} \mathrm{mL}^{-1}$, chlorpyrifos $0.25 \mathrm{mg} \mathrm{mL}^{-1}$, citronellal $0.01 \mathrm{mg} \mathrm{mL}^{-1}$ ); ectoparasiticide $B$ (cypermethrin $0.188 \mathrm{mg} \mathrm{mL}^{-1}$, chlorpyrifos $0.375 \mathrm{mg} \mathrm{mL}^{-1}$, fenthion $0.188 \mathrm{mg} \mathrm{mL}^{-1}$ ); ectoparasiticide $C$ (chlorpyriphos $0.833 \mathrm{mg} \mathrm{mL}{ }^{-1}$, cypermethrin high-cis $0.1 \mathrm{mg} \mathrm{mL}^{-1}$ ); and ectoparasiticide $D$ (ethion $0.4 \mathrm{mg} \mathrm{mL}^{-1}$, chlorpyriphos $0.212 \mathrm{mg} \mathrm{mL}^{-1}$, alpha-cypermethrin $\left.0.125 \mathrm{mg} \mathrm{mL}^{-1}\right)$. CI: confidence intervals.

$44(81.48 \%)$ of the 54 cattle farms, respectively. Conversely, the populations of ticks studied were resistant to ectoparasiticides A and D (efficiency $<95 \%$ ) in $38(70.37 \%)$ and $32(59.26 \%)$ of the 54 cattle farms, respectively (Table 1). The efficiency of a given acaricide varies greatly between different tick populations, and this depends, among other factors, on the management system in a given farm and the frequency of the ectoparasiticide application (ROCHA et al., 2011). The higher efficiency of ectoparasiticide B can be attributed to the fact that the product contained fenthion in its formulation. However, to confirm this hypothesis, in the future we must test the active principle in isolation against these tick populations. This acaricide is only recently available for cattle tick control in Brazil; accordingly, tick populations have been subjected to lower selective pressures for resistance to this chemical than to the other acaricides tested (SINDAN, 2016).

Different levels of resistance to all ectoparasiticides tested were detected. It is common for commercial products to combine active ingredients from different chemical families owing to their inefficacy when used separately (ANDREOTTI et al., 2011). However, ectoparasiticides comprising chemicals of different families were satisfactorily effective against $R$. (B.) microplus at only 11 of the 54 farms tested. Resistance to products containing a combination of SP and OP is also reported in other regions of Brazil (CAMPOS \& OLIVEIRA, 2005; MENDES et al., 2007; ANDREOTTI et al., 2011) and worldwide (FERNÁNDEZ-SALAS et al., 2012; GHOSH et al., 2015; PUERTA et al., 2015). Frequent use of chemical treatments increases the chances of selecting for resistance among ticks, which is one of the main factors in establishing a resistant population of R. (B.) microplus (RODRIGUEZ-VIVAS et al., 2006). Therefore, we consider important to emphasize the importance of constant monitoring of the acaricidal efficiency, through in vitro tests to contribute to the rational use of acaricides currently available in the market and to reduce the frequency of treatments. These measures can lead to the maintenance of parasite populations below the threshold of economic damage and contribute to a lower environmental impact (FAO, 2003). 


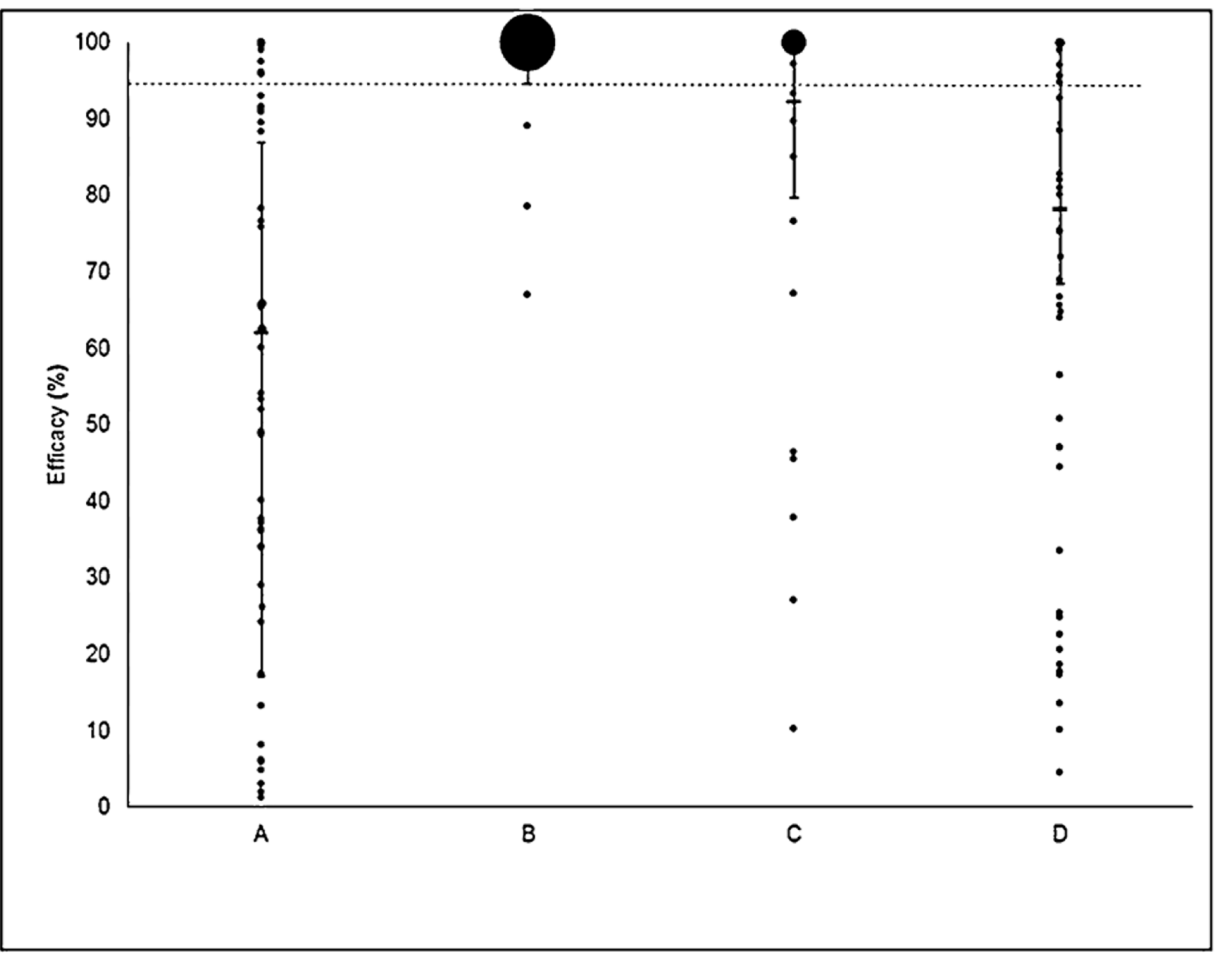

Figure 2. Distribution of efficiency of four acaricides used to control Rhipicephalus (B.) microplus on cattle farms in Rio Grande do Sul, southern Brazil. Lines indicate mean efficiency and standard error. Ectoparasiticide $A$ comprises cypermethrin $\left(0.15 \mathrm{mg} \mathrm{mL}^{-1}\right)$, chlorpyrifos (0.25 $\left.\mathrm{mg} \mathrm{mL}^{-1}\right)$, and citronellal $\left(0.01 \mathrm{mg} \mathrm{mL}^{-1}\right)$; ectoparasiticide $B$ comprises cypermethrin $\left(0.188 \mathrm{mg} \mathrm{mL}^{-1}\right)$, chlorpyrifos $\left(0.375 \mathrm{mg} \mathrm{mL}^{-1}\right)$, and fenthion $\left(0.188 \mathrm{mg} \mathrm{mL}^{-1}\right)$; ectoparasiticide $C$ comprises chlorpyriphos $\left(0.833 \mathrm{mg} \mathrm{mL}^{-1}\right)$ and cypermethrin high-cis $\left(0.1 \mathrm{mg} \mathrm{mL}^{-1}\right)$; and ectoparasiticide $D$ comprises ethion $\left(0.4 \mathrm{mg} \mathrm{mL}^{-1}\right)$, chlorpyriphos $\left(0.212 \mathrm{mg} \mathrm{mL}^{-1}\right)$, and alpha-cypermethrin $\left(0.125 \mathrm{mg} \mathrm{mL}^{-1}\right)$.

\section{Conclusion}

Only the combination of cypermethrin, chlorpyrifos, and fenthion had acceptable mean levels of efficiency in the tick populations studied. The higher efficiency of this mixture is possibly due to the presence of fenthion, probably owing to its recent commercial availability in Brazil, and consequently, lower levels of resistance established in tick populations.

\section{References}

Andreotti R, Guerrero FD, Soares MA, Barros JC, Miller RJ, Léon AP. Acaricide resistance of Rhipicephalus (Boophilus) microplus in State of Mato Grosso do Sul, Brazil. Rev Bras Parasitol Vet 2011; 20(2): 127-133. PMid:21722487. http://dx.doi.org/10.1590/S1984-29612011000200007.

Brasil. Ministério da Agricultura, Pecuária e Abastecimento. Portaria n ${ }^{\circ}$ 48, de 12 de maio de 1997. Regulamento técnico para licenciamento e/ ou renovação de licença de produtos antiparasitários de uso veterinário. Diário Oficial da República Federativa do Brasil [online], Brasília, maio 1997 [cited 2017 May 3]. Available from: http://sistemasweb.agricultura. gov.br/sislegis/action/detalhaAto.do?method=visualizarAtoPortalMapa \&chave $=72818869$

Campos DA Jr, Oliveira PR. In vitro valuation of acaricides efficiency to Boophilus microplus (Canestrini, 1887) (Acari: Ixodidae) from bovines at the region of Ilhéus, Bahia, Brazil. Cienc Rural 2005; 35(6): 1386-1392. http://dx.doi.org/10.1590/S0103-84782005000600025.
Drummond RO, Ernst SE, Trevino JL, Gladney WJ, Graham OH. Boophilus annulatus and B. microplus: laboratory tests of insecticides. J Econ Entomol 1973; 66(1): 130-133. PMid:4690254. http://dx.doi. org/10.1093/jee/66.1.130.

Fernández-Salas A, Rodríguez-Vivas RI, Alonso-Díaz MA. First report of a Rhipicephalus microplus tick population multi-resistant to acaricides and ivermectin in the Mexican tropics. Vet Parasitol 2012; 183(3-4): 338342. PMid:21824728. http://dx.doi.org/10.1016/j.vetpar.2011.07.028.

Food and Agriculture Organization of the United Nations - FAO. Producción y sanidad animal - resistencia a los antiparasitarios: estado actual com énfasis en América Latina. Roma: FAO; 2003.

Food and Agriculture Organization of the United Nations - FAO. Resistance management and integrated parasite control in ruminants: guidelines. Roma: FAO; 2004. Module 1 Ticks, Acaricide Resistance: diagnosis, management and prevention; p. 25-77.

Ghosh S, Kumar R, Nagar G, Kumar S, Sharma AK, Srivastava A, et al. Survey of acaricides resistance status of Rhipiciphalus (Boophilus) microplus collected from selected places of Bihar, an eastern state of India. Ticks Tick Borne Dis 2015; 6(5): 668-675. PMid:26117183. http://dx.doi. org/10.1016/j.ttbdis.2015.05.013.

Klafke G, Webster A, Dall Agnol B, Pradel E, Silva J, La Canal LH, et al. Multiple resistance to acaricides in field populations of Rhipicephalus microplus from Rio Grande do Sul state, Southern Brazil. Ticks Tick Borne Dis 2017; 8(1): 73-80. PMid:27717758. http://dx.doi.org/10.1016/j. ttbdis.2016.09.019. 
Mendes MC, Pereira JR, Prado AP. Sensitivity of Boophilus microplus (Acari: Ixodidae) to pyrethroids and organophosphate in farms in the Vale do Paraíba region, São Paulo, Brazil. Arq Inst Biol 2007; 74(2): 81-85.

Miller RJ, Davey RB, George JE. First report of permethrin resistant Boophilus microplus (Acari: Ixodidae) collected within the United States. J Med Entomol 2007; 44(2): 308-315. PMid:17427702. http://dx.doi. org/10.1093/jmedent/44.2.308.

Nolan J, Roulston WJ, Wharton RH. Resistance to synthetic pyrethroids in a DDT-resistant strain of Boophilus microplus. Pestic Sci 1977; 8(5): 484-486. http://dx.doi.org/10.1002/ps.2780080508.

Puerta JM, Chaparro JJ, Lopez-Arias A, Arroyave SA, Villar D. Loss of in vitro efficacy of topical commercial acaricides on Rhipicephalus microplus (Ixodida: Ixodidae) from Antioquian farms, Colombia. J Med Entomol 2015; 52(6): 1309-1314. PMid:26336268. http://dx.doi.org/10.1093/ jme/tjv129.

Reck J, Marks FS, Rodrigues RO, Souza UA, Webster A, Leite RC, et al. Does Rhipicephalus microplus tick infestation increase the risk for myiasis caused by Cochliomyia hominivorax in cattle? Prev Vet Med 2014; 113(1): 59-62. PMid:24176137. http://dx.doi.org/10.1016/j.prevetmed.2013.10.006.
Rocha CMBM, Leite RC, Bruhn FRP, Guimarães AM, Furlong J. Perceptions of milk producers from Divinópolis, Minas Gerais, regarding Rhipicephalus (Boophilus) microplus control. Rev Bras Parasitol Vet 2011; 20(4): 295-302. PMid:22166383. http://dx.doi.org/10.1590/S198429612011000400007.

Rodriguez-Vivas RI, Alonso-Díaz MA, Rodríguez-Arevalo F, FragosoSanchez H, Santamaria VM, Rosario-Cruz R. Prevalence and potential risk factors for organophosphate and pyrethroid resistance in Boophilus microplus ticks on cattle ranches from the State of Yucatan, Mexico. Vet Parasitol 2006; 136(3-4): 335-342. PMid:16413971. http://dx.doi. org/10.1016/j.vetpar.2005.05.069.

Sindicado Nacional da Indústria de Produtos para Saúde Animal SINDAN. Compêndio de produtos veterinários [online]. 2016 [cited 2016 Dec 10]. Available from: http://www.cpvs.com.br/cpvs/

Statistical Analyses Statistical - SAS. User's guide: statistics. Cary, NC, USA: SAS Institute Inc; 1985.

Vargas MS, Céspedes NS, Sánchez HF, Martins JR, Céspedes COC. In vitro evaluation of a field strain of Boophilus microplus (Acari: Ixodidae) resistant to Amitraz. Cienc Rural 2003; 33(4): 737-742. http://dx.doi. org/10.1590/S0103-84782003000400024. 